\title{
REGULATION AND THE CHALLENGE OF BROADBAND TELECOMMUNICATIONS: BACK TO THE FUTURE?
}

\author{
HUDSON JANISCH*
}

This article discusses the current state of broadband Internet service in Canada and recent regulatory disputes between the Canadian Radiotelevision and Telecommunications Commission and service providers in Canada. The article examines the difficulties experienced in the Canadian marketplace with regard to providing service to rural and remote users and compares the current delivery scheme with the Australian National Broadband Network. The article highlights the particular challenges involved in the regulation of a rapidly evolving industry such as telecommunications.
Cet article traite de l'état actuel du service Internet à large bande au Canada t des conflits réglementaires qui existent entre le Conseil de la radiodiffusion et des télécommunications canadiennes et les fournisseurs de service au Canada. L'article examine les difficultés sur le marché canadien en ce qui concerne la prestation de services aux usagers dans les régions rurales et éloignées et fait une comparaison avec la prestation de services du réseau national à large bande de l'Australie (Australian National Broadband Network). L'article souligne les défis particuliers que comporte la réglementation d'une industrie à évolution rapide comme les télécommunications.

\section{TABLE OF ConTENTS}

I. SALUTATIONS . . . . . . . . . . . . . . . . . . . . . . . 768

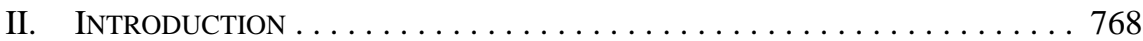

III. NETWORK EFFECTS AND ECONOMIES OF SCALE . . . . . . . . . . . 770

IV. FROM INTERCONNECTION TO OPEN ACCESS $\ldots \ldots \ldots \ldots \ldots \ldots \ldots \ldots \ldots . \ldots 71$

V. COMMON CARRIAGE . . . . . . . . . . . . . . . . . . . . . . . . . . . 772

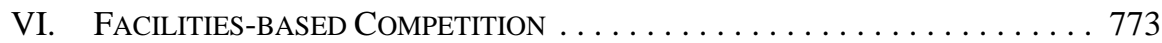

VII. FACILITIES Competition: Not GoOd ENOUGH . . . . . . . . . . . . . . . 773

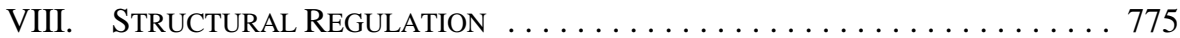

IX. THE DigitAl Divide: REgUlATORY

AND GOVERNMENTAL INITIATIVES . . . . . . . . . . . . . . . . . 775

X. The AUSTRALIAN NBN . . . . . . . . . . . . . . . . . . . . . 779

A. Combination of Technologies $\ldots \ldots \ldots \ldots \ldots \ldots \ldots \ldots 780 \ldots \ldots$

B. Commercial Viability $\ldots \ldots \ldots \ldots \ldots \ldots \ldots \ldots \ldots \ldots$

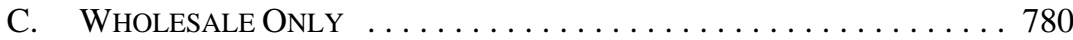

D. COMPETITION AND LAYERS $\ldots \ldots \ldots \ldots \ldots \ldots \ldots \ldots \ldots$. . . . . . . 781

E. ENTRY-LEVEL SERVICES $\ldots \ldots \ldots \ldots \ldots \ldots \ldots \ldots \ldots \ldots \ldots$

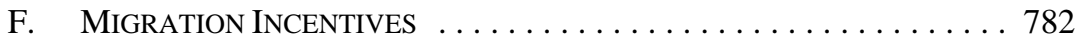

G. UNIFORM ROLL OUT . . . . . . . . . . . . . . . . . . . . . . . 782

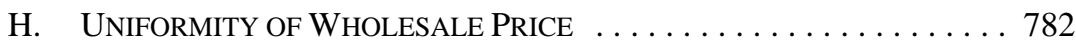

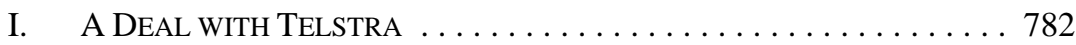

J. MONOPOLY REGULATION $\ldots \ldots \ldots \ldots \ldots \ldots \ldots \ldots \ldots \ldots$

XI. CONCLUSION .......................... 784

Inaugural TransCanada Chair in Administrative and Regulatory Law, Faculty of Law, University of Alberta; Osler, Hoskin \& Harcourt Chair of Law and Technology Professor Emeritus, University of Toronto; Adjunct Professor, Faculty of Law, University of Victoria, 2009-2011. This is a revised and updated version of a lecture given at the Faculty of Law, University of Alberta, 26 October 2010. 


\section{SALUTATIONS}

I am delighted to be here to give this lecture in my capacity as the Inaugural TransCanada Chair in Administrative and Regulatory Law at the Faculty of Law, University of Alberta. I am grateful to Dean Philip Bryden and his colleagues at the Faculty of Law for inviting me to be the first holder of the chair, and to the TransCanada Corporation for its generous support of a chair in what, I am sure, we would all agree are critically important branches of law. I see "administrative law" as mainly concerned with procedural and jurisdictional issues, while "regulatory law" is more concerned with broader, substantive outcomes. On this occasion, I will be addressing the regulatory aspect of my mandate; in the new year I hope to deal with related aspects of administrative law. The chair allows me to be in residence for a spell, and I greatly appreciate this opportunity to meet and talk with faculty and students on a range of common concerns, as well as with practitioners of regulatory law both here and in Calgary.

\section{INTRODUCTION}

I recall that in the mid-1980s I was asked by my then Dean, Robert Pritchard, about my interests and research agenda. I told him that I was, as ever, deeply into telecommunications regulation which I said was likely to last me into retirement. "You should find yourself something new to do," he insisted, "the whole thing is going to be competitive and there will be no regulation left.” Well, here we are a quarter century later, with me seven years into retirement, and telecommunications regulatory issues are as pervasive and intractable as ever. What is it about telecommunications that attracts so much regulation? Why has it not been possible to simply open up the sector to competition and close down the regulatory shop? Why, in a move towards competition, has there been even more regulation? These are some of the questions I wish to touch on in this talk. I say "touch on" because telecommunications regulation is a highly complicated business and I am sure that you would not want me to become immersed in complexity at the expense of oversight, and perhaps even insight. So I will be deliberately painting with a broad brush today. I do not by any means claim to know all the answers, but after 40 years in and out of the regulatory trenches, starting with the 1968 Bell Canada rate case,${ }^{1}$ at the very least I have a good deal of experience on which to draw. And ironically, and reassuringly for me, some of the regulatory principles I first learned in the late 1960s now appear, as we shall see, to be coming back into fashion. As the saying has it: "What goes around, comes around.”

The focus of my remarks, as the title of this talk indicates, will be on the implications for industry structure and regulation of the further rapid adoption of high capacity, fibre optic technology. This used to provide the "big pipes" which carried inter-city traffic, but now fibre is moving into neighbourhoods (referred to as fibre-to-the-node or FTTN) and even to individual premises and homes (known as FTTH). We live in a time of massive increases in the use of transmission capacity (or bandwidth) in which high quality video streaming and video conferencing are the expected norm. Just to give you some feel of where we are going, remember that $1 \mathrm{Mbps}$ (Megabits per second) constitutes basic broadband, 3.7 Mbps is the average speed of broadband in the United States, and $10 \mathrm{Mbps}$ is considered fast enough for 
business use via local area networks. The regulator, the Canadian Radio-television and Telecommunications Commission (CRTC), recently reported that 21 percent of residential Internet subscribers do so at 1.5 to $4 \mathrm{Mbps}$; 49 percent at 5 to $9 \mathrm{Mbps} ; 23$ percent at 10 to 15 Mbps; and less than 3 percent at 16 to $100 \mathrm{Mbps}^{2}$ Four percent still used "good old” dial-up wideband service at 300 to $1400 \mathrm{Kbps}$ (Kilobits per second). And here I will be talking about 100 Mbps capacity to every home! This is the sort of bandwidth which today in Canada is only employed by local area networks, Internet service providers, large corporations, and government agencies.

Before you dismiss $100 \mathrm{Mbps}$ to the home as pie-in-the-sky conjecture, let me remind you that in the United States a large telecom service provider, Verizon, has already made fibre available directly to 15 million homes and has some 4 million Internet and 3 million digital television subscribers to the Verizon FiOS network. ${ }^{3}$ Here in Canada, Videotron, the Quebec based cable company, has just claimed the blue ribbon for the fastest service of any cable operator in North America with its Ultimate Speed Internet, offering up to $120 \mathrm{Mbps}$ downstream and 20 Mbps upstream. On 22 September 2010, Robert Dépatie, President and CEO of Videotron announced: “Today, we are launching the high-speed Internet service of the future. With the pace at which users' needs are changing, we are not so far from the day when 120 mbps will be a must-have convenience." ${ }^{4}$

Of course, these pioneering ventures come with lots of caveats such as bandwidth usage caps, high cost of in-house wiring upgrades, and limited access. Even so, Videotron plans to fibre-up nearly 80 percent of its Quebec City cable footprint. And how many of us want to spend \$150 a month for $120 \mathrm{Mbps}$ of residential broadband? Nevertheless, given the continuing surge in bandwidth hungry applications, it may well be that before too long $120 \mathrm{Mbps}$ will become, as Videotron has bet, "a must-have convenience.”

Given my overall objective in this talk, this is all the technological punditry and prognosis in which I will indulge, although we will have to be sure that we do not lose sight of the crucial take-up rate as we contemplate a $100 \mathrm{Mbps}$ world. Some years back, techno-enthusiasts used to say, "Build it and they will come.” Today's post-dot.com bubble techno-realists say, "Build it and they may come.” It is one thing to put huge capacity in place, quite another to ensure its commercial viability.

CRTC, Communications Monitoring Report (July 2011), online: CRTC < http://www.crtc.gc.ca/eng/ publications/reports/policymonitoring/2011/cmr2011.pdf > at 141.

3 Verizon was one of the first major US carriers to offer fibre to the home, and it received positive ratings from Consumer Reports: "Fiber-Optic Providers Are Leading Choices for Internet, TV, and Telephone Service," Consumer Reports (5 January 2010), online: Consumer Reports <http://pressroom.consumer reports.org/pressroom/2010/01/fiberoptic-providers-are-leading-choices-for-internet-tv-and-telephoneservice.html>.

$4 \quad$ Videotron, Press Release, “Videotron Ultimate Speed Internet 120TM: Québec City Gets Canada’s Fastest Internet Access Service” (21 September 2010), online: Videotron < http://corpo.videotron.com/ site/press-room/press-release/441>. 


\section{NETWORK EFFECTS AND ECONOMIES OF SCALE}

There are two basic economic principles at work in telecommunications - network effects and economies of scale. ${ }^{5}$ In most markets, consumers do not much care how many other consumers purchase the same thing they do. But as a network industry, telecommunications is different in that the value of the network to each user, and hence their willingness to pay, increases with every addition of other users to the network. Moreover, non-interconnecting competing networks misallocate society's scarce resources away from their most productive use. Network effects are concerned with the value of service to each customer, while economies of scale are concerned with decreasing per-customer cost of providing service. If economies of scale keep increasing, at some point a single firm can serve the whole market with lower overall costs per-customer than can multiple firms. Such a market is said to be a "natural monopoly."

Traditionally, telecommunications was treated as a natural monopoly with governments providing legally protected monopoly franchises in exchange for commitments to provide a reasonable level of service at reasonable rates. There was thus no need for competition which would only dilute the incumbent's economies of scale. Most importantly, from a public policy perspective, monopoly provided a means for cross-subsidies to achieve "universal service” such as those from business to residential, long distance to local, and urban to rural. However, by the 1980s basic universal service had been largely achieved in countries with highly developed telecommunications industries, and greater emphasis came to be placed on achieving higher rates of technological and marketing innovation through competition which could also drive down prices.

But how was competition to be achieved in the face of the incumbent's economies of scale and network effects? It was soon realized that the benefits of competition could not be achieved without some form of interconnection to the incumbent's network. Without a right of interconnection, a new entrant could not offer its customers effective service capable of reaching all the people customers wished to call unless it first built a new ubiquitous physical network whose geographic scope rivalled that of the dominant network, and found some way of underwriting that network without passing on its unusually high per-customer costs to its initially small customer base.

To be effective, interconnection required close supervision from a specialist regulator. Only New Zealand decided not to impose sector-specific regulation, relying instead on general competition law. When I spoke at a Pacific Telecommunication Conference there in 1992, I was roundly denounced by the Minister in charge for advocating heavy handed Canadian regulation. However, by 2006 it was evident that the desired results of competition were not being achieved and an increasingly demanding regulatory regime has since been put in place in New Zealand.

For an excellent, brief summary of the implications of economic principles in telecommunications and its regulation, see Jonathan E Nuechterlein \& Philip J Weiser, Digital Crossroads: American Telecommunications Policy in the Internet Age (Cambridge, MA: MIT Press, 2005) at 3-22. This text also provides a useful guide to the transition away from monopoly towards competition and the challenge this constituted to regulatory principles established during the monopoly period. See also Gerald W Brock, The Telecommunications Industry: The Dynamics of Market Structure (Cambridge, MA: Harvard University Press, 1981); Alvin von Auw, Heritage \& Destiny: Reflections on the Bell System in Transition (New York: Praeger, 1983); Eli M Noam, ed, Telecommunications Regulation Today and Tomorrow (New York: Harcourt Brace Jovanovich, 1983); John T Wenders, The Economics of Telecommunications: Theory and Policy (Cambridge, MA: Ballinger Publishing, 1987). 


\section{FROM INTERCONNECTION TO OPEN ACCESS}

Although interconnection was thus seen as essential to the successful introduction of competition, its implementation ran headlong into the strong economic (and even emotional) incentives of the incumbent not to allow competitors access to its network. I vividly recall the sense of outrage of Jean de Grandpré, the imperious CEO of Bell Canada in the 1980s, when, under cross-examination at the CRTC, he drew himself up and scornfully remarked: "It's a strange kind of competition when you want to come onto my network to compete against me."”

Be that as it may, fully-fledged open access policies, which later supplemented interconnection, required incumbents to make available to their competitors, usually at regulated rates, various unbundled parts of their networks so that competitors may choose what components they want to use as part of their service without having to replicate the full investment incumbents originally made. As you may imagine, this is an extremely difficult and contentious process.

Despite all the difficulties in implementation, open access was seen as lowering entry barriers because new entrants would not be required to build their own ubiquitous networks before competing with dominant carriers. But even then, given initial lack of economies of scale and high fixed and sunk costs to be incurred, as opposed to the marginal costs of incumbents for each additional customer, difficulties facing new entrants encouraged regulators to keep access rates artificially low, while handicapping incumbents by subjecting them to bundling, pricefloor, and win-back restrictions. The challenge has been to balance the dangers of contrived competition against the benefits of having at least some competition, even if far removed from the model of "perfect" competition economists dream about.

Given the immense capacity of an all-optical fibre network and its huge upfront installation cost, concerns for economies of scale are once again front and centre in telecommunications regulation. It needs to be kept in mind that much of this initial expense is in relatively low-tech civil engineering work - digging trenches, locating and filling ducts, getting into homes. The cost of the fibre itself and of the associated electronics is miniscule relative to the cost of lowtech, high labour components.

Whatever form they take, these costs will lead to determined counterattacks from incumbents to prevent, or at least restrict, competitor access to their advanced fibre optic networks at regulated prices which are not seen as fully compensating them for their investment. And there will be equally determined challenges by would-be competitors fearful of losing customers if they are excluded from high-capacity new networks. Two spectacular instances of these clashing imperatives come to mind.

Deutsche Telekom, still owned in part by the German government, invested over 3 billion Euros in a new, high-speed advanced fibre network. The government persuaded the Bundestag to pass legislation exempting Deutsche Telekom's new network for a time from generally 
applicable access requirements. It argued that it was entitled to recover its massive investment, while competitors complained that they would be substantially disadvantaged if deprived of access. The European Union's Telecommunications Commissioner insisted that the proposed “temporary monopoly” violated European telecommunications law. Meanwhile, in Australia, the incumbent Telstra was required by its regulator to give its competitors access to its newly upgraded network. Under the governing statutory regime, it had to give "exclusive use" of parts of its network to competitors. This, Telstra argued, amounted to a “compulsory acquisition," or expropriation, of its property without adequate compensation in violation of the Australian Constitution.

In the end, the incumbents lost in both cases - the European Court of Justice siding with the Telecommunications Commissioner ${ }^{7}$ and the High Court of Australia seeing regulation, not unlawful expropriation. ${ }^{8}$ These high-level challenges show just how determined regulators, incumbents, and competitors are to refight access issues in the new broadband technological context. We do seem to be going back to the future.

\section{COMMON CARRIAGE}

Indeed, we may be going back very far as suggested in an article in The Economist in May 2010. ${ }^{9}$ It argued that what is needed today in telecommunications regulation is a reaffirmation of the ancient principles of “common carriage,” first articulated in Emperor Justinian's Digest of Roman Law. In the eighteenth century, William Blackstone, in his famous Commentaries on the Laws of England, said that innkeepers who open houses for travelers imply "an engagement to entertain all persons who travel that way." "The article describes how "English common law came to see innkeepers, boatmen, warehouse owners and granary operators as "common carriers': transport trades compelled to serve all comers, and to charge reasonable rates." ${ }^{\text {"11 }}$ Most importantly for us, the idea of common carriage was later applied by statute to telegraph and telephone natural monopolies, enshrining non-discrimination and just and reasonable rates in regulatory law.

Unjust discrimination and undue preference remain central ideas in today's telecommunications regulation. Thus when the CRTC came to address the contentious issue of "net neutrality" in its October 2009 review of traffic management practices of Internet service providers, ${ }^{12}$ it relied on section 27(2) of the Telecommunications $A c t^{13}$ which provides: "No Canadian carrier shall ... unjustly discriminate or give an undue or unreasonable preference toward any person, including itself, or subject any person to an undue or unreasonable disadvantage.” This allowed it to craft a relatively narrow, complaints driven, non-

\footnotetext{
Deutsche Telekom AG v European Commission, C-280/08 P, [2010] ECR I-0000 [Deutsche Telekom]. Telstra Corporation Limited v The Commonwealth, [2008] HCA 7 [Telstra].

"From ships to bits: common carriage is an ancient idea being applied to a modern problem - internet access," The Economist (13 May 2010), online: Economist <http://www.economist.com/node/ 16106593>.

Ibid.

Ibid.

CRTC, Review of the Internet traffic management practices of Internet service providers (21 October 2009), Telecom Regulatory Policy 2009-657, online: CRTC < http://www.crtc.gc.ca/eng/archive/2009/ 2009-657.htm>.
}

13 SC 1993, с 38. 
discriminatory approach rather than get drawn into an extravagant concept of net neutrality in which all content providers pay the same price and have the same access to final consumers.

However, the introduction of various forms of competition has gone far to undermine the cogency and coherence of common carriage, as such competition runs counter to the underlying monopoly rationale for common carriage. It is as if, to go back to Blackstone's boatmen, a rival ferry had been authorized and the original ferry operator was required to allocate space on his boat to additional competitors at regulated rates. If common carrier obligations were an appropriate response to monopoly, the issue now is what aspects of it, if any, should be retained in an era of competition? Of course, should the economies of scale inherent to fibre optic broadband networks require us to think once again about natural monopolies, then common carriage concerns will return as part of our journey back to the future.

\section{FACILITIES-BASED COMPETITION}

Unlike other parts of the world, North American competition has largely taken the form of facilities-based, inter-modal competition between telecommunications companies (telcos) and cable companies (cablecos). Rather than under-financed new entrants confronting high entry barriers of economies of scale and network effects, cable companies brought with them their own networks and established customer bases. In 2005 when I was part of a team at Telus working on a submission to the influential Telecommunications Policy Review Panel, our mantra was, "Cable Changes Everything." 14 Indeed cable companies, which used to confine themselves to the distribution of television signals, now are major providers of high-speed Internet service with 55 percent of all high-speed residential subscribers. ${ }^{15}$ In 2005 , cable companies started to provide local telephone service over managed IP networks. By the end of 2010 they had captured some 26 percent of local residential lines to become major competitors of the incumbent telephone companies which had had a century-old monopoly on local telephone service. ${ }^{16}$ Most importantly, this allows them to provide a full bundle of competitive telephone, Internet, television, and wireless services.

\section{FACILITIES CoMPETITION: NoT GOOD ENOUGH}

Despite these major shifts in the marketplace, the CRTC is not satisfied that duopoly telco/cableco competition by itself best serves the interests of Canadian consumers. This can be seen in a recent CRTC decision mandating "speed matching," that is to say a requirement that incumbent telcos and cablecos provide wholesale services at regulated rates which will enable competitors to offer Internet services to their customers at speeds which match those provided to their own retail customers. ${ }^{17}$ The CRTC was of the view that without this regulatory initiative, there would not be an adequate level of competition. ${ }^{18}$ As CRTC Chairman, Konrad von

For a valuable critical assessment of Canadian telecommunications regulation, see Telecommunications Policy Review Panel, Final Report 2006 (Ottawa: Public Works and Government Services Canada, 2006), online: Industry Canada <http://www.ic.gc.ca/eic/site/smt-gst.nsf/vwapj/tprp-final-report2006.pdf>.

Communications Monitoring Report, supra note 2 at 142.

Ibid at 127.

CRTC, Wholesale high-speed access services proceeding (30 August 2010), Telecom Regulatory Policy CRTC 2010-632 at para 29, online: CRTC < http://www.crtc.gc.ca/eng/archive/2010/2010-632.htm> [Wholesale high-speed proceeding].

Ibid. 
Finckenstein explained, this was necessary, “[o]therwise, you get a very cozy oligopoly running the business.... (Independent ISPs) are the ones who provide innovation and the competitive spark and make sure that consumers don't suffer."19

As was to be expected, and as foreshadowed in the Deutsche Telekom and Telstra cases, the incumbent companies, especially Bell Canada, argued that this type of access decision would inevitably deter future network investment. “[R]egulated access,” BCE Inc (Bell Canada) President and CEO George Cope warned, "will have significant implications for our network and other investments going forward." ${ }^{20}$ And Kevin Crull, President of Bell Residential Services, added, "[i]f this decision stands, we will have to revise the pace, extent and location of our network roll-out." 21

The conditional "if this decision stands" reflects the extent of the current tension between the federal cabinet and the independent regulatory commission. Indeed, when the CRTC had initially ruled in favour of speed matching, the cabinet had directed it to reconsider whether that approach would unduly reduce incentives to invest in new network infrastructure. In reaffirming its initial decision, the CRTC decided that the telcos and cablecos would be allowed an additional 10 percent mark-up on the regulated rates at which they provided facilities to ensure speed matching. Given the outraged tone of Bell's press release following the decision, this move would seem to have done nothing to placate them.

In what had been a particularly tense hearing, Cope had suggested that mandated access was like requiring Tim Hortons to sell its coffee to corner stores. Rather than let it go as a flippant analogy, the CRTC Chairman immediately pounced on it, saying that the iconic coffee chain was not part of a network and that "if Tim Hortons went out of business, it wouldn't be a national tragedy." 22 The hearing room erupted in laughter with many suggesting that they begged to differ.

These CRTC hearings were particularly testy given the sharp differences between the incumbents and would-be competitors. When Cope was asked to discuss his company's plans for further investment in a next-generation network, he tartly responded that he was unwilling "to talk about future technology with our cable competitors in the room." 23 This reticence provoked the CRTC's Chairman von Finckenstein to tell assembled telecom executives: "I'm tired of being misled by you guys not answering my questions." ${ }^{24}$

In light of Bell Canada’s umbrage, reminiscent of Jean de Grandpré's outraged rejoinder, it is interesting to note that Timothy Denton, a CRTC Commissioner with extensive experience

Althia Raj, “CRTC rules in favour of smaller Internet providers,” The Toronto Sun (31 August 2010), online: The Toronto Sun <http://www.torontosun.com/news/canada/2010/08/30/15189481.html>. BCE Inc (Bell Canada), News Release, "BCE appeals CRTC decision that discourages investment in next-generation networks" (12 March 2009), online: Bell Canada <http://www.bce.ca/news-andmedia/releases/show/bce-appeals-crtc-decision-that-discourages-investment-in-next-generationnetworks?page $=1$ \&perpage $=10$ \&year $=2009 \&$ month $=3 \&$ keyword $=>$.

21 Ibid.

22 Iain Marlow, "BCE head slams the CRTC,” The Globe and Mail (31 May 2010), online: The Globe and Mail <http://www.theglobeandmail.com/report-on-business/bce-head-slams-the-crtc/article1389830/>

23 Iain Marlow, “Telecom's top brass lock horns at CRTC Hearings,” The Globe and Mail (3 June 2010), The Globe and Mail <http://www.theglobeandmail.com/report-on-business/telecoms-top-brass-lockhorns-at-crtc-hearings/article1372338/>. Ibid. 
with independent Internet service providers, dissented in part on the grounds that, while a good decision, it did not go far enough. He thought that the regulator should have taken additional steps to restrain the ability of incumbents to modify portions of the network in their own interest. This would have enabled competitors to get behind traffic management measures imposed by the incumbent carriers. Only then, Denton believed, would the regulatory decision have ensured significant service innovation. ${ }^{25}$

Denton's dissent makes for particularly interesting reading in light of recent criticism that the Government of Canada has not pushed hard enough on the access front, or fostered really effective facilities-based competition. ${ }^{26}$ An overall critique of telecommunications regulation in Canada is that it has fallen between two stools - on the one side, not enough facilities-based competition, in large measure due to highly restrictive rules on foreign ownership, and an insufficiently aggressive access regime on the other. A combination of relatively weak intermodal competition and an equally weak access regime may constitute a worst-of-all-worlds Canadian compromise.

\section{STRUCTURAL REgULATION}

Nor has Canada mandated any changes in industry structure to alter adverse incentives, thereby easing the need to monitor behaviour. Possible regulation should reinforce, not run counter to incentives. In theory, it should be possible to regulate to prevent an incumbent, which has an incentive to discriminate against a competitor accessing its network, from doing so. In practice, discrimination often takes too subtle a form for the regulator to detect and guard against. It has accordingly been suggested that a structural rather than a regulatory approach should be adopted. This has led to what is known as "functional separation," in which the incumbent is required to segregate its business into retail and wholesale components. Additionally, the incumbent must charge the same wholesale network access rates and give an equivalent level of access to both its competitors and its own retail component. This approach has been adopted in the United Kingdom, where British Telecom now has a separate unit, Openreach, which sells open access components to telecommunications providers including British Telecom's retail operations. Functional separation has also been adopted in New Zealand. $^{27}$

\section{THE Digital Divide: REGULATORY AND GOVERNMENTAL INITIATIVES}

The range of new services available on broadband, especially for hospitals and schools, has tended to exacerbate concerns about an urban/rural digital divide. Here in Canada, both the Dissenting in Part.

26 The Berkman Center for Internet \& Society at Harvard University released a study which stated,“Canada looks like a case where the concern for incumbent investment incentives, without quite reaching to the level of [regulatory] abstention, resulted in a weaker version of unbundling than was implemented in many of the other countries we reviewed here”: Berkman Center for Internet \& Society at Harvard University, Next Generation Connectivity: A review of broadband Internet transitions and policy from around the world, Report (February 2010) at 163, online: Berkman Center for Internet \& Society at Harvard University < http://cyber.law.harvard.edu/sites/cyber.law.harvard.edu/files/Berkman_Center_ Broadband_Final_Report_15Feb2010.pdf $>$. 
federal and provincial governments have sought to promote broadband in unserved, as well as underserved, areas in a variety of ways. ${ }^{28}$

At a provincial level, most provinces have tended to pair up with either local communities or smaller private operators to provide additional broadband connectivity. For example in Alberta, the \$330 million Alberta SuperNet (which has private and public components) has an optic fibre network connecting 4,700 sites (provincial government and municipal offices, health and education sites, and libraries) in 27 urban and well over 400 rural communities. ${ }^{29}$ On the government side of things, the Alberta SuperNet has been very effective in extending government services across the province, and in centralizing service delivery and telecommunications spending in a single network. However, it may be less effective as an enabler of broadband connectivity in rural Alberta: “The top-down, 'build it and they will come' approach to deploying the network has been widely criticized for failing to engage local communities."30

In the 2009 federal budget, \$225 million was set aside for “development and implementation of a strategy to extend broadband coverage."31 This will involve the government funding up to 50 percent of the costs of organizations selected to provide at least $1.5 \mathrm{Mbps}$ service. ${ }^{32}$ This has led to difficult issues in coordinating initiatives, with the steady spread of high-speed service into rural areas by the incumbents and private sector initiatives already underway. ${ }^{33}$ As well, there are challenging institutional design issues in ensuring effective public/private collaboration. ${ }^{34}$ Moreover, a striking regulatory brouhaha resulted when the CRTC sought to get in on the act.

For reasons outlined earlier, there has always been a temptation for regulators to take steps to bolster the likelihood of successful competitive entry. This has been especially so with respect to local service, where entry barriers were seen as particularly high. This led the CRTC in 2002 to insist that incumbents not lower local urban rates but freeze them and place excess revenue in deferral accounts. The regulator hoped that by keeping local rates artificially high, new competitors would be encouraged to enter the last monopoly bastion. Despite these good intentions, sustained local competition was to come, not from new entrants, but from established

$28 \quad$ Ibid at 254.

29 See Alberta's Super Net Home Page, online: <www.thealbertasupernet.com>.

30 Catherine A Middleton \& Jock Given, "Open Access Broadband Networks in Alberta, Singapore, Australia and New Zealand” (Paper delivered at the 2010 Telecommunications Policy Research Conference), [published online in the Digital Commons @ Ryerson by the Ted Rogers School of Information and Technology Management Publications and Research] at 11, online: Digital Commons @ Ryerson <http://digitalcommons.ryerson.ca/cji/viewcontent.cgi?article=1022\&context=trsitm>.

31 Industry Canada, News Release, "Minister Clement Announces First Projects to Receive Broadband Canada Funding” (9 May 2010), online: Industry Canada <http://www.ic.gc.ca/eic/site/ic1.nsf/eng/ 05530.html>.

32 Ibid.

33 See Iain Marlow, "Rural Internet firms irked by federal funds for rivals,” The Globe and Mail (9 June 2010), online: Globe Advisor <https://secure.globeadvisor.com/servlet/ArticleNews/story/gam/2010 0609/FINALBROADBANDGOVERNMENTATL>; Iain Marlow, "Fourth-generation wireless: A tale of two providers," The Globe and Mail (7 October 2010), online: CTV News <http://www.ctv.ca/ generic/generated/static/business/article1746126.html>.

34 See Iain Marlow \& Jacquie McNish, “Canada’s digital divide,” The Globe and Mail (3 April 2010), online: The Globe and Mail < http://www.theglobeandmail.com/technology/canadas-digital-divide/ article137255/?page=all>; Iain Marlow, "Rural Canada loses as politics and business fail to get broadband down the last mile,” The Globe and Mail (15 November 2010), online: The Globe and Mail <http://www.theglobeandmail.com/news/national/time-to-lead/rural-canada-loses-as-politics-andbusiness-fail-to-get-broadband-down-the-last-mile/article1315241/>. 
cable companies employing IP technology on their coaxial networks which allowed them to do an end-run around the copper-based local monopoly.

Over $\$ 1.5$ billion in excess local rates ended up in escrow and a nasty squabble broke out as to how this pot of money should be divided up. Consumer representatives argued that it should be returned to consumers who had been overcharged. The companies urged that it should be allocated to them to upgrade high-speed service to rural and remote communities. The CRTC initially ruled that funds in deferral accounts should be used to improve access to telecommunications services by persons with disabilities and to expand high-speed service in unserved or underserved areas. ${ }^{35}$ The legality of this decision was eventually upheld in the Supreme Court of Canada. ${ }^{36}$ However, the CRTC subsequently changed its mind, and more recently ruled that about half of the remaining funds in the deferral accounts should be returned to consumers, with the rest being used on high-speed networks in rural and remote areas. ${ }^{37}$ Michael Janigan of the Public Interest Advocacy Centre, who had fought the good fight for consumers for over eight years, politely characterized this decision as "a reasonable conclusion to a flawed regulatory adventure." 38 And so it might simply have been had there not been a hugely important additional wrinkle in the CRTC decision which had significant implications for the whole broadband policy debate.

In the Deferral Account Proceeding, the CRTC directed Bell Canada to deploy broadband services in rural and remote areas comparable to the services it provided in urban areas. In its rollout plan, Bell Canada proposed to offer an advanced wireless broadband service that would provide up to 2 Mbps download speed and up to 800 Kbps upload speed, with a 2 Gigabyte monthly usage allowance. This usage allowance was lower than comparable wireless services in urban areas. This led the CRTC to insist that Bell Canada extend its wireline DSL (Digital Subscriber Line) service instead. ${ }^{39}$

Mirko Bibic, Bell Canada's Senior Vice-President for Regulatory and Governmental Affairs, was highly critical of the decision, saying that the regulator appeared to be incapable of forward-looking analysis by ignoring inevitable future wireless network upgrades and sticking consumers with old, non-upgradeable DSL. ${ }^{40}$ In any event, "regulators should not be choosing technologies, the market should."

Significantly, there was a strong dissent from Len Katz, Vice-Chairman of Telecommunications at the CRTC. He argued that the decision ran counter to the

CRTC, Disposition of funds in the deferral accounts (16 February 2006), Telecom Decsion CRTC 20069 at paras 77-80, online: CRTC <http://www.crtc.gc.ca/eng/archive/2006/dt2006-9.htm>. Bell Canada v Bell Aliant Regional Communications, 2009 SCC 40, [2009] 2 SCR 764.

CRTC, Follow-up to Telecom Decision 2008-1 — Proposal by Bell Aliant Regional Communications, Limited Partnership and Bell Canada to dispose of the funds remaining in their deferral account (31 August 2010), Telecom Decision CRTC 2010-637 at paras 45-57, online: CRTC <http://www.crtc. gc.ca/eng/archive/2010/2010-637.pdf > [Deferral Account Proceeding].

Public Interest Advocacy Centre (PIAC), Media Release, "PIAC calls CRTC deferral accounts decision a reasonable conclusion to a flawed regulatory adventure" (31 August 2010), online: PIAC <http:// www.piac.ca/telecom/crtc_deferral_accounts_backgrounder_for_today_s_decision/>.

Deferral Account Proceeding, supra note 37 at paras 29-35.

Iain Marlow, "CRTC to hand over phone rebates,” The Globe and Mail (31 August 2010), online: CTV News <http://www.ctv.ca/generic/generated/static/business/article1691790.html>. Ibid. 
Telecommunications Act which recognized the need to adopt new and innovative technology. ${ }^{42}$ "By limiting the rollout of broadband services in these communities to DSL technology," he remarked, "the Commission has taken a static view of technology and failed to recognize the dynamic changes taking place in functionality and cost from newer technologies." 43 He also noted that the ruling ran counter to the principle of technological neutrality in regulatory decision making. Incumbents should be free to employ new and innovative technologies, as long as they meet the price, quality, reliability, service, and access conditions imposed by the Commission. ${ }^{44}$

Cope was also highly critical of the CRTC's majority decision, which he saw as undermining Bell Canada's plan to roll out advanced wireless broadband technology in many smaller communities. “Considering the federal government's commitment to ensuring Canada's leadership in the digital economy and its strong support for intensified investment in the latest broadband technologies, this is quite frankly a shocking decision by the CRTC." ${ }^{45}$ He went out of his way to endorse Katz's concern that the majority had adopted a static view of technology.

Two months later, in response to requests from Bell Canada to review its decision, the CRTC backed down and endorsed Katz's position and the deployment of wireless technology. As the CRTC now put it: "The Commission considers that, consistent with the principle of technological neutrality, the Bell companies should be able to deploy the technology of their choice as long as its broadband service meets the required criteria and does not exceed the \$306.3 million previously approved for wireline DSL technology.”46 Mirko Bibic observed, with evident satisfaction: "It does indicate that the commission is finally prepared to accept superior wireless technology as a broadband alternative." ${ }^{, 7}$ Even more importantly, it gave some indication that the CRTC, once bitten, twice shy, might be prepared to leave it largely up to the incumbent telecommunications companies to determine the rate and level at which further broadband service would be introduced in Canada.

At the outset of the CRTC hearings which were to address broadband Internet access, von Finckenstein noted: "The burning question now becomes whether the commission has a role to play in the provision of broadband Internet services where it is currently not available." ${ }^{\text {48 }}$ The incumbents argued strongly that no regulatory intervention was called for. As Telus put it, "[s]ince satellite, cable, copper, and wireless options will, in combination, provide 100 per cent broadband coverage, all without regulation, there is clearly no need to revise the [basic service

$42 \quad$ Supra note 13, s 7(g).

$43 \quad$ Deferral Account Proceeding, supra note 37 at Dissenting Opinion of Commissioner Len Katz.

44 Ibid.

Bell Canada, News Release, "Bell disappointed with CRTC decision denying rural and remote communities the latest wireless broadband network technology” (1 September 2010), online: Bell Canada <http://www.bce.ca/news-and-media/releases/show/bell-disappointed-with-crtc-decision-deny ing-rural-and-remote-communities-the-latestbr-wireless-broadband-network-technology >.

46 CRTC, Bell Canada - Applications to review and vary certain determinations in Telecom Decision 2010-637 concerning the use of high-speed packet access wireless technology and the deferral account balance (29 October 2010), Telecom Decision CRTC 2010-805 at para 19, online: CRTC < http:// www.crtc.gc.ca/eng/archive/2010/2010-805.htm>.

47 Iain Marlow, "Bell wins nod to use wireless option in rural Web rollout," The Globe and Mail (31 October 2010), online: The Globe and Mail <http://www.theglobeandmail.com/technology/bell-winsnod-to-use-wireless-option-in-rural-web-rollout/article1215975/>.

48 Iain Marlow, “Northern high-speed Internet focus of hearings,” The Globe and Mail (26 October 2010), online: The Globe and Mail <http://www.theglobeandmail.com/technology/northern-high-speed-internet -focus-of-hearings/article1381193/>. 
obligation] to include broadband." 49 By and large, the CRTC agreed with this approach, although it did reserve the right to set (modest) target speeds.

The CRTC was satisfied that the rollout of broadband Internet access had been successful through a combination of market forces, targeted funding, and public-private partnerships at all levels of government. This meant that virtually all Canadians, regardless of whether they live in urban centres or in rural or remote areas, benefit from having access to broadband using a variety of technologies. At the same time, the CRTC noted that the ubiquity and speed of broadband Internet access at reasonable rates was becoming increasingly more important for Canadians in the achievement of a number of social, economic, and cultural objectives. This suggested that, at least, the establishment of a target speed for broadband access available universally to all Canadians was required in the public interest. This was set at a minimum of 5 Mbps download and 1 Mbps upload by $2015 . .^{50}$

A fully-fledged optical fibre-based high-speed network (with satellite and fixed wireless in very remote areas) covering all of Canada, capable of providing service up to $100 \mathrm{Mbps}$, would have required a completely different approach. At the CRTC hearings, MTS Allstream Inc (MTS Allstream) estimated that it would cost about \$7 billion to roll out high-speed Internet to remote areas. This, MTS Allstream emphasized, could not be achieved by market forces alone, but would require large-scale government funding. This caused Katz to question "whether spending $\$ 7$ billion to provide 100-per-cent broadband penetration would be a good use of [public] money, given that many Canadians still don't sign up for the [existing broadband] service." 51

This modest, almost reticent, political and regulatory response to broadband in Canada makes the Australian National Broadband Network (NBN) initiative all the more amazing for us.

\section{The Australian NBN}

The NBN dramatically addresses all the issues raised earlier from economies of scale and natural monopoly: competition, incentives, structural separation, government investment, and the urban/rural digital divide.

Very briefly stated, the Labour Party in opposition in 2007 proposed an upgrade to a FTTN network which would assure virtually everybody $12 \mathrm{Mbps}$ broadband service. Two years into office in April 2009, the Labour Government announced plans for a blockbuster 100 Mbps FTTP National Broadband Network with a $\$ 43$ billion price tag over eight years. ${ }^{52}$ A year later, a detailed study by consultants McKinsey \& Company and accountants KPMG confirmed that

Iain Marlow, “Telus rejects Internet 'obligation to serve,”” The Globe and Mail (26 April 2010), online: The Globe and Mail <http://www.theglobeandmail.com/technology/telus-rejects-internet-obligation-toserve/article1367109/>.

$50 \quad$ CRTC, Obligation to serve and other matters (3 May 2011), Telecom Regulatory Policy CRTC 2011291 at paras 76, 79, online: CRTC <http:// www.crtc.gc.ca/eng/archive/2011/2011-291.pdf>.

51 Iain Marlow, "Service for north, rural areas pegged at \$7-billion," The Globe and Mail (28 October 2010), online: Globe Advisor < https://secure.globeadvisor.com/servlet/ArticleNews/story/gam/2010 1028/RBCRTCINTERNETFINALATL $>$.

52 Minister for Broadband, Communications and the Digital Economy (Australia), Joint Media Release, "New National Broadband Network" (7 April 2009), online: Senator the Hon Stephen Conroy <http:// www.minister.dbcde.gov.au/media/media_releases/2009/022>. 
the NBN was achievable within the projected budget. ${ }^{53}$ In the 2010 federal elections, the NBN was attacked by the conservative Coalition opposition as an extravagant waste of money. Interestingly, their so-called minimalist proposal to incrementally upgrade existing broadband networks, would have cost taxpayers well over \$6 billion. It would seem that enthusiasm for broadband, in some form or another, is widespread Down Under. As Jock Given of Swinburne University succinctly put it, "[w]e’re all tech heads now."

In the end, after a very close election, the Labour Party was returned to office only with the support of two rural independents who said that their backing was predicated on the rapid implementation of the NBN. They had extracted a number of additional promises with respect to implementation designed to further assist their constituents in rural and remote areas.

Time will not allow for anything approaching a full analysis of this fascinating initiative, so I will have to confine myself to ten salient points. ${ }^{55}$

\section{A. Combination OF TECHNOLOgIES}

The NBN Implementation Study concluded that 93 percent of all premises could be reached by a 250,000 kilometre fibre network, fixed wireless could reach the next 4 percent, and satellite the final 3 percent of premises. It recognized that this new fibre infrastructure will entirely redefine the current industry structure and supersede the historic copper network. ${ }^{56}$

\section{B. COMMERCIAL VIABILITY}

In a post-Reagan-and-Thatcher world, even a Labour government had to couch its NBN policy in commercial viability terms, thereby leaving itself open to sustained attack on the sufficiency of a 6 percent return on investment and the prospect of any private sector involvement which would expect at least 15 percent return on its investment. Significantly, the Implementation Study is much less optimistic about private sector investment in the NBN than the initial government proposal. ${ }^{57}$

\section{WhOlesale ONLY}

Defining the NBN's mandate as "wholesale only" was crucial to achieving government competition objectives. The plan is to have a government-owned network, run by NBN Co, which will provide open access to its broadband network to competitors. Keeping NBN Co strictly out of the retail market is intended to eliminate incentives to discriminate, thereby

Australia, Department of Broadband, Communications and the Digital Economy, National Broadband Network Implementation Study (6 May 2010) at 204, online: Department of Broadband, Communications and the Digital Economy <http://www.dbcde.gov.au/_data/assets/pdf_file/0020/ 127550/NBN-Implementation-Study-complete_report.pdf> [Implementation Study].

54 Jock Given, "We're all tech heads now," Inside Story (23 August 2010), online: Inside Story <http:// inside.org.au/we-are-all-tech-heads-now/>.

55 For a useful review of the many regulatory issues raised, see Australia, Department of Broadband, Communications and the Digital Economy, National Broadband Network: Regulatory Reform for 21st Century Broadband (April 2009), online: Department of Broadband, Communications and the Digital Economy <http://www.dbcde.gov.au/_data/assets/pdf_file/0006/110013/NBN_Regulatory_Reform_ for_the_21st_Century_Broadband_low_res_web.pdf $>$. Implementation Study, supra note 53 at 8-9. Ibid at 41-44. 
enhancing competition. ${ }^{58}$ It has long been an article of faith in Australia that the vertical and horizontal integration of the incumbent, Telstra, has prevented the emergence of a truly competitive telecommunications industry. Somewhat ironically, a government-owned monopoly is seen as the means of ensuring a vibrant private-sector retail competitive market. However, legislation introduced by the Minister for Broadband, Communications and the Digital Economy, which grants a wide ministerial discretion to allow NBN Co into certain retail markets, threatens to undermine this pro-competition rationale for the NBN. "The long-term worry,” Jock Given observed, "is that a government responsible for an investment of this scale will be tempted to shape the activities of its wholly owned NBN Co and the regulation of the industry to shore up its returns." 59

\section{COMPETITION AND LAYERS}

An analogy is sometimes made to highways and trucking in which the government builds the highway and competing trucking companies run on it. So it is said that a government-owned electronic highway can have competing service providers running on it, a best-of-all-worlds solution in which the government provides the passive natural monopoly infrastructure, and the private sector provides the competing innovative services.

However, a broadband network is not a strip of asphalt but a complex, layered electronic composite in which competitors will need to access and manipulate. If competitors are to provide innovative new services, they need access to the network hardware and should not be confined to merely ride on top of the network. Layer 1 constitutes the passive fibre network itself. Layer 2 consists of the active electronic equipment needed to send information across the network and on which the wholesale services will be offered to retail service providers. Layer 3 will be where retail service will be offered to consumers. While Layer 1 will be a monopoly, and Layer 3 hopefully highly competitive, just how much competitive access there will be to Layer 2 remains highly contentious. The Implementation Study favoured a short-term NBN Co monopoly over Layer 2, despite its concern that this may stifle innovation and the efficient provision of competitive retail services. ${ }^{60}$

\section{E. ENTRY-LEVEL SERVICES}

While 100 Mbps may have been a great political selling point in the government's proposal, it was not supported by the more sober NBN Implementation Study, which saw 20 Mbps as a realistic entry-level broadband service. ${ }^{61}$ Given fibre's capacity, there would be no need for usage caps, and in response to ever-increasing new bandwidth-hungry applications, fibre would offer almost unlimited upgrade potential and future proofing. ${ }^{62}$ This primary reliance on optical fibre makes an interesting contrast with Bell Canada's commitment to make extensive use of broadband wireless discussed earlier.

Jock Given, “Inside Conroy’s Implement,” Inside Story (16 May 2010), online: Inside Story <http:// inside.org.au/inside-conroys-implement>.

Implementation Study, supra note 53 at 48-50.

Ibid at 34.

Ibid at 13 . 


\section{F. MigRATION INCENTIVES}

The NBN Implementation Study suggested that incentives would be required to encourage users to switch to NBN-based services, especially in view of the cost involved in acquiring equipment to work with fibre, such as new wiring and batteries. It proposed a migration payment of $\$ 300$ per premise - a total of $\$ 3.3$ billion for all premises to be served by fibre by $2018 .^{63}$

\section{G. UNIFORM ROLL OUT}

As originally announced, the NBN rollout would not have given priority to the most commercially attractive areas, which made for good politics but bad economics. However, the Implementation Study suggested that in view of the need for early revenue, the rollout schedule could be tailored to improve return by focusing initially on areas where the rate of take up would be the greatest, or where the cost of deployment would be least. ${ }^{64}$ Such an approach now appears to be off the table in view of the agreement between the Labour Party and the two independent rural MPs on whose support the continued viability of the government depends. It provides: "As the NBN is built, regional areas will be given priority to ensure they can more quickly overcome the 'digital divide' they have experienced for too long.... NBN Co will bring forward the introduction of wireless services and satellite services so that regional Australia can get access to better broadband straight away." 65 The rural tail seems to be wagging the national $\operatorname{dog}$ !

\section{H. UNIFORMITY OF WHOLESALE PRICE}

The NBN Implementation Study made it clear that "uniformity of wholesale access pricing should apply only within access technology platforms and not universally across fibre, wireless and satellite." ${ }^{\prime 66}$ It was expected the wholesale entry prices would be similar, but not necessarily identical to entry-level services on fibre. ${ }^{67}$ However, the agreement with the independent MPs provides that "broadband prices will be the same for households and businesses regardless of where they are located - in the city, in regional Australia or in more remote parts of the country." ${ }^{68}$ Of course, their concern was with retail prices which will be set competitively outside the control of NBN Co, but wholesale rates will have a substantial influence on retail price levels.

\section{A DEAL WITH TELSTRA}

On 20 June 2010, a $\$ 9$ billion tentative deal was announced between the incumbent Telstra and the government. It provides for the reuse of suitable infrastructure including ducts and

\footnotetext{
$63 \quad$ Ibid at $246-47$.

$64 \quad$ Ibid at 46 .

65 Letter from Australian Prime Minister Julia Gillard to Tony Windsor, MP [nd] enclosing The Australian Labor Party \& the Independent Members (Mr. Tony Windsor and Mr. Rob Oakeshatt ('the Parties') Agreement (7 September 2010) at 6 (Annex B), online: Tony Windsor MP <http://www.minister. regional.gov.au/files/Regional_Agreement.pdf $>$ [ALP Agreement]. Implementation Study, supra note 53 at 34. Ibid. ALP Agreement, supra note 65 at 6 (Annex B).
} 
backhaul fibre by NBN Co as it starts to rollout its new network, thereby avoiding unnecessary infrastructure duplication. As well, it will provide for the progressive migration of customers from Telstra's copper network to the new fibre network. After two years of complex negotiations, definitive agreements have been reached between Telstra and NBN Co. Shareholder approval for these agreements was obtained at Telstra's Annual General Meeting on 18 October $2011 .^{69}$ After insisting on a series of revisions, Telstra's structural separation undertaking was finally approved by the Australian Competition and Consumer Commission (ACCC) on 27 February 2012. ${ }^{70}$

\section{J. MONOPOLY REgULATION}

Finally, in order to capture the massive economies of scale on a national fibre broadband network, the Australian government is taking a journey back to the monopoly origins of telecommunications.

Although the telecommunications industry had been long treated as a "natural” monopoly protected from competitive entry by economies of scale and network effects, these economic defences were often reinforced by legal restrictions on competition. What was particularly to be guarded against was "cherry-picking," in which competitors moved in on commercially attractive network segments, thereby undermining the incumbent's ability to cross-subsidize the spread of service and achieve the full benefits of economies of scale in a single firm. There is now concern that the NBN will face similar selective competitive entry which will undermine uniform affordable prices. However, rather than proposing an outright ban on cherry-picking, the NBN Implementation Study suggested that non-NBN broadband be required to build to the same technical standards as the NBN and offer similar open access and wholesale equivalence. If cherry-picking were to emerge as a concrete threat during the NBN build, the NBN Implementation Study further suggested that the government might wish to implement temporary protection for NBN Co against the commercial impact of cherry-picking beyond the setting of technical standards and ensuring open access and equivalence. Rather than an outright prohibition on competing networks which would reduce innovation and remove the discipline of competitive pressure from NBN Co, it was thought that the simplest disincentive against cherry-picking would be to impose a levy on cherry-pickers payable to government, with the proceeds directed towards telecommunications subsidy programs. However, it was thought that, in practice, so long as NBN Co operated efficiently and responsibly, it was doubtful that significant networks would be built when forced to offer open and equivalent access to wholesale services, even in the absence of a levy. ${ }^{71}$

As well, a whole new regulatory regime will have to be put in place to ensure that NBN Co earns a reasonable rate of return on its investment, but does not exploit monopoly rents. ${ }^{72}$ In the first skirmish over NBN wholesale rates, the ACCC has made it clear that it will be a demanding regulator. As the Commission's Chairman, Rod Sims, put it: “The NBN will be a national, wholesale-only, fixed line network monopoly. As the interests of monopolies and consumers

Telstra, Office of Company Secretary, "Results of Annual General Meeting” (18 October 2011), online: Telstra <http://www.telstra.com.au/abouttelstra/download/document/tls804-agm-proxies-2011.pdf>.

“Assessment of Telstra's Structural Separation Undertaking and draft Migration Plan,” online: ACCC <http://www.accc.gov.au/content/index.phtml/itemId/1003999>.

Implementation Study, supra note 53 at 463-67.

Ibid at 32-34. 
are not always the same, it is necessary that there is a robust regulatory regime in place to address excessive prices and ensure fair access to the network."73 Of course, this going back to the future will not involve going back to a single vertically integrated service provider as in the "bad old days," but will be combined, as we have seen, with retail competition. While the NBN Implementation Study hoped that regulation could be avoided at the Layer 3 retail level, this will depend on a comprehensive ex ante resolution of complex issues with respect to the nature of open access to Layer 2. Layer 1 is envisaged as a classic public utility in need of monopoly regulation. This may prove to be difficult, as NBN Co will likely be fully government-owned at least through to the end of rollout, and the government will not take kindly to regulatory decisions which make it more difficult to achieve its political ambitions. There will be a delicious tension between the government wanting higher wholesale rates in the short term to pay down its investment, thereby satisfying taxpayers generally, and lower rates over the long term which will encourage greater take up and commercial viability, thereby satisfying information consumers.

\section{Conclusion}

It is fascinating to compare and contrast the approaches adopted in Canada and Australia. In Canada, the gamble is that the market, combined with a modest level of government support, will put in place technology capable of being upgraded to meet future bandwidth-hungry applications and which will incrementally close the urban/rural divide. In Australia, the gamble is that there will be sufficient take up of the NBN to warrant the huge public investment involved, and that retail competition will thrive when dependent on a monopoly broadband wholesaler. In the language of an older technology — radio — we will all need to "stay tuned.”

In coming to the end of my journey, I am once again reminded why I continue to find the telecommunications industry and its regulation so endlessly challenging and fascinating. Like Lon Fuller, I believe that law, especially regulatory law, is best viewed as a continuing challenge rather than as a finished project. ${ }^{74}$ The need to be constantly prepared to reconsider and reassess was captured well by David Colville, an experienced Canadian telecommunications regulator, when he observed: "There will never be a state of rest, an end point for companies or for public policy."75 And, as the great realist, Benjamin Cardozo, wrote of the dynamic nature of law many years ago: "Nothing is stable. Nothing absolute. All is fluid and changeable. There is an endless 'becoming.", 76

ACCC, News Release, “ACCC reinforces NBN access regulatory role” (30 September 2011), online: ACCC <http://www.accc.gov.au/content/index/phtml/itemId/1010026/fromItemId/621277>. See also Henry Ergas, "The gouge is on for NBN Users," The Australian (26 August 2011), online: The Australian <http://www.theaustralian.com.au/news/opinion/the-gouge-is-on-for-nbn-users/story-e6frg 6zo-1226122392946>.

74 Lon L Fuller, The Morality of Law, revised ed (New Haven, CT: Yale University Press, 1969) at 106, 145.

75 David Colville, “Regulation Transformed: Competition’s First Decade” (Paper delivered at the Celebrating 10 Years of Telecom Competition — Understanding the Past — Building the Future Conference, Toronto, 7 June 2002).

76 Benjamin N Cardozo, The Nature of the Judicial Process (New Haven, CT: Yale University Press, 1921) at 28 . 